\title{
The increase of the life quality for patients who had a cerebrovascular accident by using the MBT physiotherapy device
}

\author{
Danelciuc Francisc Tadeus², Sînziana Călina Silisteanu², Danail Sergiuª \\ ${ }^{1}$ Kinetic therapist - "Stefan cel Mare" University of Suceava \\ ${ }^{2}$ Railway Hospital Iasi - Specialty Ambulatory of Suceava - "Stefan cel Mare" University of Suceava \\ ${ }^{3}$ Phd - USEFS, Chisinau, Republica Moldova
}

\begin{abstract}
The cerebrovascular accident is a major health issue, with medical and economic consequences upon the society. The cerebrovascular accident determines the sensorial and motor impairment, the speech and postural control impairment. Some patients who had a cerebrovascular accident may have difficulties in the response to the postural perturbations. Some patients who had a cerebrovascular accident may have difficulties in the response to the postural perturbations. The recovery of the postural control and of the balance depends on the quality of the motor action in order to use the ADL and to ensure the social and professional reintegration of the patients. That is why the postural control is essential in the recovery of the patients who had a cerebrovascular accident. The current study aims at the possibilities to regain the postural control for the patients with motor deficit by an individual program of recovery sessions. The current trial aimed at finding the way in which it is possible to influence the quality of life for the patients who had a cerebrovascular accident by using the MBT physiotherapy device. The use of the MBT physiotherapy devices in the recovery programme of the postural control after the cerebrovascular accident involves the need to set up an individualized programme of kinetic therapy. According to the established deficiency, namely the average one and the slight one, the recovery programme would need the introduction of techniques and methods whose effect is to reeducate the postural function. This can be done more easily if the recovery is initiated by using the MBT physiotherapy device that can intervene in the functional recovery which corresponds to each recovery stage.
\end{abstract}

Key words: cerebrovascular accident, MBT physiotherapy device, postural control

\section{Introduction}

The cerebrovascular accident is a major health issue, with medical and economic consequences upon the society. The 35-65year-old patients are affected the most frequently whereas the European statistics show an annual incidence of 300 new cases/100,000 inhabitants. Almost one fourth of the patients who had a cerebrovascular accident die during the first 30 days and approximately $50 \%$ die during the first 6 months. The survivors have an increased risk in order to develop a new cerebrovascular accident stroke whereas the recovery takes months.

The risk factors involved in the causes of a cerebrovascular accident and that may be modified are: the high blood pressure, the diabetes mellitus, the hyper cholesterolemia, the heart conditions (the atrial fibrillation, the valvular conditions and the cardiomyopathy), smoking, the sedentary behaviour, the obesity and the drug consumption. The risk factors that may not be modified are: the age, the human race, the genetic predisposition and the gender.

The cerebrovascular accident determines the sensorial and motor impairment, the speech and postural control impairment.[1] The postural control involves the activity of several cerebral parts, being the result of the interaction among the body systems that contribute to the control of the temporal and spatial orientation as well as the control of the balance. [1, 2, 3] That is why the control posture at all times is a basic condition for the stability, for the daily activities (the ADL) and the initiation of the voluntary 
movements. [4, 5, 6] The cerebral lesions may determine a perturbation in the postural control according to the sizes and the location of the lesion, the age and the comorbidities of the patient. [7,8,9]

The most frequent used fundamental positions after the cerebrovascular accident are when the patients lie down, sit down and standing up. The latter allow the evaluation of the patients, the recovery and subsequently, the transfer to / from the bed, the ability to sit down on the chair/to stand up from the chair as well as the ability to maintain the orthostatism without any support. [8]

According to the statistics, a week after the cerebrovascular accident, approximately $40 \%$ of the patients cannot make the transfer. Subsequently, a month later, only $60-70 \%$ of the patients make this transfer by their own, $20-25 \%$ by support but $10-15 \%$ cannot make it.

The independence of the patients who had a cerebrovascular accident means the ability to regain the position by sitting down on their own. $[10,11,12]$ Some patients who had a cerebrovascular accident may have difficulties in the response to the postural perturbations. [13] The spasticity may influence the dynamic postural stability and the coordination between the poster and the movements. [14,15,16,17]

The muscular force at the level of the sick lower limb can make the patients who had a cerebrovascular accident to lack balance while they sit down, having importance in the reeducation of the static and dynamic balance. [17,18,19]

The cerebrovascular accident is associated to the alteration of the static and dynamic balance in the orthostatism, to the ability to walk and to sit down. There occurs the modification of the balance between the agonist musculature and the antagonist one in the chain of the cinematic chains, especially the balance of the lower limbs, with the alteration of the mechanisms of sensitive and motor integration, by influencing the functions of control - coordination - balance and implicitly the postural control. [20]

Two hypotheses related to the postural control were stated. [21]

According to the reflex - hierarchic theory, the posture and the balance are influenced by independent sensorial systems. Thus, there are progressive modifications from the early spinal reflexes to the complex reactions due to the cortical response. [1]

The second theory, namely the theory of the systems, suggests that the interaction among persons, the purpose of the movement and the environment result in the postural control. The latter involves the postural control of the body in space, namely the interaction between the myo-arthrokinetic system and the neural one. [22]

The recovery of the postural control and of the balance depends on the quality of the motor action in order to use the ADL and to ensure the social and professional reintegration of the patients. That is why the postural control is essential in the recovery of the patients who had a cerebrovascular accident. There are trials by which the MBT physiotherapy device intervenes in the ability to gain the postural balance and to improve it for different pathologies. The current study aims at the possibilities to regain the postural control for the patients with motor deficit by an individual program of recovery sessions.

The balance and the stability also involve the coordination.

- the muscular control is the result occurred from an activated group of motor units belonging to the muscles involved in the motor activity.

- the coordination is the resulted of the activated contraction schemes for several muscles (a minimal number of muscles involved in the performance of a movement). The balance is maintained by the postural reflexes that are triggered by the sensorial systems (the visual one and the vestibular one) and by the receptors (the proprioreceptor and the exteroreceptors). [23]

The balance control is provided by the nervous system that processes the 
information and the neural-muscular-osteojoint systems that deal with the movement in order to maintain the balance.

Under normal circumstances, the balance is automatically achieved as a consequence of the interaction among the specialized systems. The pathologic cases need the conscious action that may remove the abnormal sensations.

The vestibular and ocular reflex has an important role in maintaining the posture, especially when it has been noticed that a simple blinking may determine an anterior/posterior movement of the trunk. After analyzing the cinematics of the trunk and of the abdomen in the vertical posture on different postures, with open/shut eyes, the normal patients were recorded to have increased the number of their movements at these levels while their eyes were shut. [24]

Another important reflex is the vestibular spinal one that controls the stability and the posture, especially during the movement . It is also known that the tonus of the extensors is enabled on the side of the inclined head whereas the tonus of the flexors is enabled on the opposite side. [24]

That is why the integrity of the SNC is important in order to process the information received from the sensorial systems and to emit signals for the performing component, namely the skeleton muscles.

The postural orientation and the stability are very important in the postural control. The postural orientation is the ability to support the body segments among them and to support the body in the environment in order to carry out the motor activity. [16, 25,26$]$

The steady orthostatic position of the body is necessary for the development of the functional tasks. This is the result of the interaction among the sensorial system, the vestibular one and the motor one. .[16, 27, 28]

The postural stability is determined by the steady balance when the myo-arthrokinetic system intervenes and it imposes the patients to keep the projection of the weight centre inside the support basis. [29] The steady stability is a dynamic process that involves the ability to stabilize and to destabilize the action forces. Under each leg at rest there are points of the pressure centre but the main pressure centre is in the middle of the support basis. In order to keep a steady position, it is possible to react by moving the weight centre or by increasing the support basis. [30] The postural orientation is more important than the stability. [31]

\section{Objectives}

The current trial aimed at:

- analyzing the efficiency of the recovery programme by kinetic therapy, namely of the postural control for the patients who were diagnosed with a cerebrovascular accident;

- making in stages the recovery programme of the postural control for the patients who had a cerebrovascular accident;

- planning and adapting the recovery programme of the postural control for the patients who had a cerebrovascular accident by using the MBT physiotherapy device;

- at finding the way in which it is possible to influence the quality of life for the patients who had a cerebrovascular accident by using the MBT physiotherapy device;

The use of the MBT physiotherapy devices in the recovery programme of the postural control after the cerebrovascular accident involves the need to set up an individualized programme of kinetic therapy. The recovery of the walk and of the balance is important for the patients who had a cerebrovascular accident;

The calculation of the statistic parameters was used for the statistic analysis and interpretation: the arithmetic average, the standard average deviation, the variability coefficient and the Pearson correlation coefficient. 


\section{Material and method}

The trial aimed at determining the particular features of the recovery programme and at evaluating the severity of the postural balance difficulties for the patients who had a cerebrovascular accident.

Several scales were used for the clinical and functional evaluation for the patients who had a cerebrovascular accident.

- the evaluation of the muscular force in order to analyse the motor deficit by using the Medical Research Council scale [32, 33, 34]

- the modified Ashworth scale in order to evaluate the muscular tonus (spasticity). [35]

- the Berg scale for the evaluation of the balance [36]

- the Quality of Life Scale (QOLS) for the evaluation of the life quality

The MBT physiotherapy devices determines instability during the walk in the anterior and posterior side and in the median and lateral side, contributing to the tonification of the musculature that stabilizes the anterior and lateral muscles of the shin, to the increase of the joint mobility, especially on the dorsal flexion and the tonified posterior musculature of the shin.

The physical exercise programme enables the functional recovery and also the development of the social professional psychical and communicative functions.

The stages of the recovery programme involve:

- the development of the basic physical qualities;

- the use of the adequate motor skills

- the development of the myoarthrokinetic sense;

- the provision of the self-control ability in order to avoid accidents;

- the steady correct apposition of the body;

- the provision of making an individual programme

THE TRIAL was made for a group of 98 patients out of which 60 men and 38 women. The average age was $57.6+/-7.8$ years.
Graph no. 1 The distribution of the trial group according to the gender

\section{The distribution of trial group} according to the gender

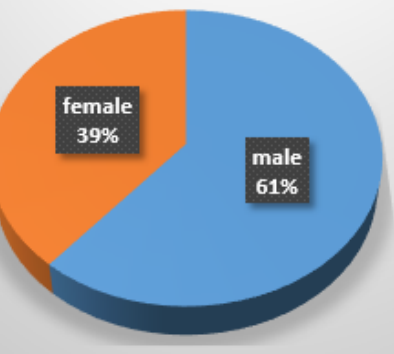

male female

After evaluating the neurological signs, it was possible to notice the presence of the spasticity in 37 patients $(37.7 \%)$ and the presence of sensitivity modifications in 25 patients (25.5\%).

The degree of the motor deficit was quantified by using the Medical Research Council scale (MRC). After the evaluation, the patients were divided into two groups: 37 patients (37.75\%) got F4 whereas 61 patients (62.24\%) got F3.

Graph no. 2 The distribution of the trial group according to the muscular force

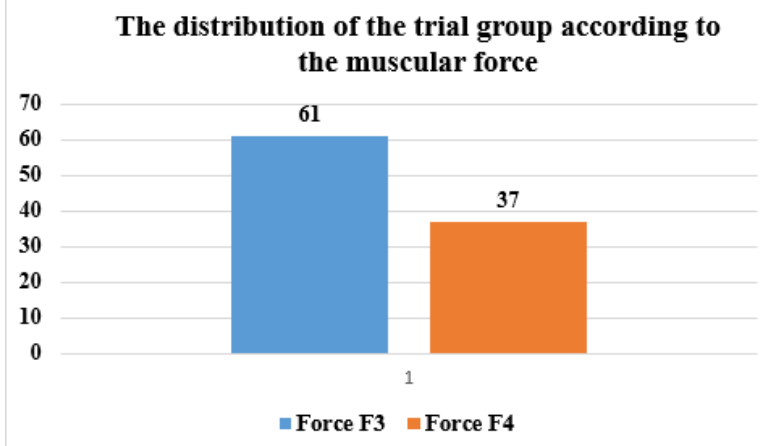

By taking into consideration that the aspects presented above, it is possible to state that there should be classical kinetic therapy made in the acute period by using enabling techniques, the Bobath method and the Kabat method. Another used scale was the PASS scale for the evaluation of the balance. There was a group of 56 patients who had a slight deficit of balance and who were evaluated three weeks after the beginning of the cerebrovascular accident, then 8 weeks after and 12 weeks after. The results of the evaluation pointed out a score of 2-4 points 
(out of 36) four weeks later, then 12-22 points (out of 36) eight weeks later and finally 25-31 points (out of 36) twelve weeks later.

Table no.3 The distribution of the patients in the trial group according to the muscular force

\begin{tabular}{|c|c|c|}
\hline Deficiency/reeks & Slight deficiency (points) & Average deficiency (points \\
\hline 4 weeks & 2 points -4 points & 14 points -17 points \\
\hline 8 weeks & 12 points -22 points & 18 points -23 points \\
\hline 12 weeks & 25 points - 31 points & 24 points -30 points \\
\hline
\end{tabular}

A group made up of 42 patients with average balance deficiency was evaluated at the same time interval whereas the obtained results pointed 14-17 points (out of 36) four weeks later, 18-23 points (out of 36) eight weeks later and 24-30 points (out of 36) twelve weeks later.

The increase quality of the life quality was evaluated with the help of the QOL scale whereas the results are presented in Table no. 4 and in the Graph no. 3

Table no.4 Evaluation of the life quality

\begin{tabular}{|l|c|c|}
\hline Statistical elements & QOL FINAL & QOL CONTROL \\
\hline MEDIANA & 0.5704 & 0.846 \\
\hline Standard deviation & 0.0654 & 0.0901 \\
\hline Student t-test & 0.0224 & 0.0206 \\
\hline
\end{tabular}

The evolution of the QOL parameter

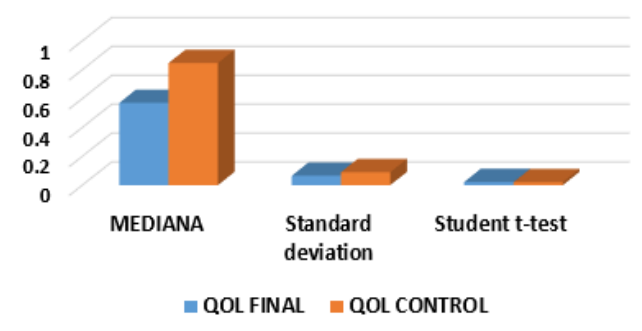

Graph no.3 The evolution of the QOLS parameter

According to the QOL scale, the results are statistically signifficantat the final/control moments with $\mathrm{p}<0.05$.

\section{Results}

According to the PASS scale, the most severe disorders are in the time interval 4-8 weeks since the outbreak of the disease whereas the easiest ones after 10 weeks since the outbreak.
After analyzing the dynamic recovery of the postural balance and of the stability, we can assert the practical efficiency of the used means in the functional recovery of the body posture especially from the spatial point of view and the importance of creating physiological mechanisms that could help to regain the motor skills.

According to the established deficiency, namely the average one and the slight one, the recovery programme would need the introduction of techniques and methods whose effect is to reeducate the postural function.

This can be done more easily if the recovery is initiated by using the MBT physiotherapy device that can intervene in the functional recovery which corresponds to each recovery stage.

\section{Conclusions}

The physical exercises program will be applied according to the possibility to request the analyzers (the exteroreceptors), the position and the posture of the body during the activities, the ability to involve the body segments while carrying out the recovery program.

The stages of the recovery program for the creation of the motor skills depends on the verbal orders, the practical presentation of the elements that have to be made up, the division into stages and structures.

This is aimed at learning correctly and recovering the necessary in keeping the posture, the balance and the coordination of the movements.

\section{References}

1. Agapii E. Recuperarea controlului postural la persoanele după accident vascular cerebral în baza programei de kinetoterapie cu efecte de transfer funcţional. Teză de dr. în pedagogie. Chişinău, 2011. p. 172.

2. Agapii E., Danail S., Pascal O. Recuperarea controlului postural la persoanele după accident vascular cerebral în baza programei de kinetoterapie cu efecte de transfer funcțional. Chișinău: USEFS, 2010, p.120.

3. Cojocariu D., Danail S., Agapii E., Pascal O. Recuperarea cordonării și a echilibrului în activitățile de bază la persoanele după accident vascular cerebral prin tehnici de biofeedback stabiligrafic. Chișinău: USEFS, 2013. p.180. 
4. Danelciuc. F.T., Silisteanu,C., The recovery of the postural equilibrium by balancing the baric pressure at the level of the lower limbs for patiens who had a stroke by using the MBT device, Iasi, 2016.

5. Groppa S., Zota E., Manea D. Profilaxia accidentului vascular cerebral ischemic. USMF „N.Testemiţanu”. Chişinău, 2006, p. 5 - 6.

6. Pendefunda L. Terapia maladiilor neurologice, Iași: Contact Internațional, 1995, p. 89101.

7. Pendefunda, L., Recuperarea bolnavului hemiplegic adult. Iaşi: Contact Internaţional,1992, p. 235.

8. Stegen. C., Zum einfuss der MBT auf die lebensqalitat von Patienten mit chronichen ruckenschmerzen. Diplomarbeit Deutsche Sporthochschule ein kinesiology.Koln 2002.

9. Wikstrom, E.A., Arrigenna, M.A., Tillman, M.D., Borsa, P.A. (2006) - Dynamic Postural Stability in Subjects With Braced, Functionally Unstable Ankles, PubMed, J. Athl. Train. (vol. 41), pag. 245250;

10. Zaharia C., Elemente de patologie a aparatului locomotor, București: Paideia, 1994. p. 2534, 65-68, 79, 133, 205-226.

11. Lephart, Sm., Proprioception and Neuromuscular Control in Joint Stability. Human Kinetics, 2000;

12. Solopova I.A., Kazennikov O.V., Deniskina N.B. et al. Postural instability enhances motor responses to transcranial magnetic stimulation in humans. In: Neuroscience Letter, 2003, vol. 337, p. $25-28$

13. Carr JH, Shepard RB, Nordholm L, Lynne D. Investigation of a new motor assessment scale for stroke patients. Phys Ther 1985; 65: 175-180;

14. Moţet D. Psihologia recuperării handicapurilor neuromotorii. Partea I. Bucureşti: 2001, p. 57 - 64 .

15. Robănescu N., Reeducarea neuromotorie. București: Medicală, 1992,

16. Sbenghe T. Kinesiologie. Ştiinţa mişcării. Bucureşti: Medicinală, 2002,pg. 365-395;

17. Fulg-Meyer, A.R, The post-stroke hemiplegic patient. Goteborg: Journal of rehability Med., 1975, nr. 7, p. 73-83.

18. Gordon J., Motor Control Workshop for Physical Therapists. Sweden: Umea. June 1997.

19. Jackson R.T., Epstein CM, De L'Amme WR. Abnormalities in posturography and estimations of visual vertical and horizontal in multiple sclerosis. Am J Otol 1995; 16: 88-93;

20. Adrian A., Constantin A. Asistenţa în Familie a Persoanei cu Deficienţă Funcțională Tehnici de îngrijire şi manevrare a bolnavului, Iași: Polirom, 2001. p. 67-72.

21. Agapii E., Danail S., Pascal O. Recuperarea controlului postural la persoanele după accident vascular cerebral în baza programei de kinetoterapie cu efecte de transfer funcțional. Chișinău: USEFS, 2010, p.120.

22. Albu C., Vlad T, Leonard \& Iacob, Ioa, Psihomotricitatea. Iași: Institutul European, 2006. p. 9-12.

23. Hamill, J. \& Knutzen, K.M. (2009) Biomechanical Basis of Human Movement, 3rd ed., Lippincott, Williams \& Wilkins, Baltimore, ISBN 07817-3405-3;

24. Dimulescu D., Chiriți G., Terapia posturală în afecțiunile aparatului locomotor. din București: Universității din București, 2008, 167 p.

25. Horak F.B., Postural orientation and equilibrium. What do we need to know about neural control of balance to prevent falls Age Ageing, 35 (Suppl 2): 117, 2006.

26. Pascal O. Tulburări ale controlului postural la bolnavii cu accident vascular cerebral: aspecte neurofiziologice, clinice şi de recuperare. Chişinău: Teză de dr. hab. în medicină. 2008, p. 207.

27. Robănescu N., Reeducarea neuromotorie. București: Medicală, 1992,

28. Shumway-Cook A, McCollum. Assessment and treatment of balance disorders in the neurologic patient. In.: Montgomery T, Connolly B, eds. Motor control and physical therapy: theoretical framework and practical applications. Chattanoga TN: Chattanoga Copr., 1990: 123-138.

29. Cordun M. Postura Corporală Normală și Patologică, ANEFS. București 1999, p. 51,53,55.

30. Zoltan P. Rolul stretchingului în normalizarea funcţiei stato-kinetice. Iaşi: Corsan, 2009, p. 47.

31. Danelciuc, F.T., Danail.S., Dan. M., Sindroamele asociate și influența acestora în manifestarea tulburărilor posturale la persoanele post AVC, în cadrul Congresului Științific Internațional "Spot. Olimpism. Sănătate" Chișinău; USEFS, 58.10.2016.

32. Calais-Germain, Blandine, Anatomie pentru mișcare. Introducere în analiza tehnicilor corporale, vol.1, Iași: Editura Polirom, 2009. p. 40-48.

33. Cordun M. Postura Corporală Normală și Patologică, ANEFS. București 1999, p. 51,53,55.

34. Cordun M. Kinantropometrie, Bucureşti: CD PRESS, 2009, p. 188-191.

35. Flora D. Tehnici de bază în kinetoterapie. Oradea: Editura Universităţii din Oradea, 2002, p. 2529, 34-37, 56-60.

Roxana P., Rodica T., Badea P., Ghid de evaluare clinică și funcțională în recuperarea medicală. Craiova: Medicală Universitară, 2004. p. 91-92; 139155; 215-218; 360-373; 